\title{
Exposure to traffic-related air pollution and changes in exhaled nitric oxide and DNA methylation in arginase and nitric oxide synthase in children with asthma
}

N. Ji', M. Fang ${ }^{1}$, A. Baptista², C. Cepeda', M. Greenberg ${ }^{2}$, I. Colon Mincey ${ }^{3}$, P. Ohman-Strickland ${ }^{1}$, F. Haynes ${ }^{1}$, N. Fiedler ${ }^{1}$, H. M. Kipen ${ }^{1}$ and R. J. Laumbach ${ }^{1 *}$

\begin{abstract}
Background: Traffic-related air pollution (TRAP) has been associated with increased risk of airway inflammation in children with asthma. While epigenetic changes could potentially modulate TRAP-induced inflammatory responses, few studies have assessed the temporal pattern of exposure to TRAP, epigenetic changes and inflammation in children with asthma. Our goal was to test the time-lag patterns of personal exposure to TRAP, airway inflammation (measured as fractional exhaled nitric oxide, FeNO), and DNA methylation in the promoter regions of genes involved in nitric oxide synthesis among children with asthma.

Methods: We measured personal exposure to black carbon (BC) and FeNO for up to 30 days in a panel of children with asthma. We collected 90 buccal cell samples for DNA methylation analysis from 18 children (5 per child). Methylation in promoter regions of nitric oxide synthase (NOS1, NOS2A, NOS3) and arginase (ARG1, ARG2) was assessed by bisulfite pyrosequencing. Linear-mixed effect models were used to test the associations of $B C$ at different lag periods, percent DNA methylation at each site and FeNO level.

Results: Exposure to BC was positively associated with FeNO, and negatively associated with DNA methylation in NOS3. We found strongest association between FeNO and BC at lag $0-6 \mathrm{~h}$ while strongest associations between methylation at positions 1 and 2 in NOS3 and BC were at lag 13-24 h and lag 0-24 h, respectively. The strengths of associations were attenuated at longer lag periods. No significant associations between exposure to TRAP and methylation levels in other NOS and ARG isoforms were observed.

Conclusions: Exposure to TRAP was associated with higher levels of FeNO and lower levels of DNA methylation in the promoter regions of the NOS3 gene, indicating that DNA methylation of the NOS3 gene could be an important epigenetic mechanism in physiological responses to TRAP in children with asthma.
\end{abstract}

Keywords: Traffic-related air pollution, DNA methylation, Asthma, Exhaled nitric oxide

\footnotetext{
* Correspondence: laumbach@eohsi.rutgers.edu

${ }^{1}$ Rutgers, The State University of New Jersey, 170 Frelinghuysen Rd, Room 204, Piscataway, NJ 08854, USA

Full list of author information is available at the end of the article
}

(c) The Author(s). 2021 Open Access This article is licensed under a Creative Commons Attribution 4.0 International License, which permits use, sharing, adaptation, distribution and reproduction in any medium or format, as long as you give appropriate credit to the original author(s) and the source, provide a link to the Creative Commons licence, and indicate if changes were made. The images or other third party material in this article are included in the article's Creative Commons licence, unless indicated otherwise in a credit line to the material. If material is not included in the article's Creative Commons licence and your intended use is not permitted by statutory regulation or exceeds the permitted use, you will need to obtain permission directly from the copyright holder. To view a copy of this licence, visit http://creativecommons.org/licenses/by/4.0/. The Creative Commons Public Domain Dedication waiver (http://creativecommons.org/publicdomain/zero/1.0/) applies to the data made available in this article, unless otherwise stated in a credit line to the data. 


\section{Background}

Exposure to traffic-related air pollution (TRAP) has been linked to a number of adverse health outcomes, and the Health Effect Institute (HEI) concluded that exposure to TRAP is causally associated with asthma exacerbation among children [1]. Here, we define TRAP as the air pollutants emitted from motor vehicle engines. Major constituents of TRAP include carbon monoxide (CO), oxides of nitrogen (NOx), volatile organic compounds (VOCs), and particulate matter (PM). Black carbon (BC) is a relatively specific marker for diesel engine-derived TRAP that is ubiquitous in urban communities and typically more intense near major roadways, seaports, and other centers of commercial activity. Airway inflammation is a key step in a hypothesized mode of action by which exposure to TRAP is thought to exacerbate asthma. Higher level of fraction of exhaled nitric oxide (FeNO), a marker of airway inflammation, was observed after short-term exposure to TRAP [2-4]. Elevated level of FeNO has, in turn, been associated with airway hyperresponsiveness and exacerbation of asthma [5]. These findings suggest that nitric oxide (NO) production in the respiratory tract plays an important role in asthmatic airway's response to TRAP.

There is increasing evidence that TRAP-induced changes in FeNO may at least partly result from epigenetic modifications that alter the expression of genes involved in the synthesis of NO. NO can be synthesized from L-arginine by three NO synthase (NOS) isoforms: (a) neuronal NOS ( $n N O S$ encoded by NOS1); (b) inducible NOS ( $i N O S$ encoded by NOS $2 A$ ); and (c) endothelial NOS (eNOS encoded by NOS3) [6]. In addition, there are two isoforms of Arginase (ARG) (encoded by $A R G 1$ and $A R G 2$ ), which compete with NOS for the L-arginine substrate [7]. Therefore, epigenetic modifications that alter the expression of NOS and ARG may modulate production of $\mathrm{NO}$ in the respiratory tract and hence FeNO.

Exposure to air pollution has been associated with changes in DNA methylation in the promoter regions of NOS or ARG suggesting a mode of action by which air pollution may alter NO production and FeNO. However, the current epidemiological evidence regarding exposure to TRAP and changes in FeNO and DNA methylation has three main limitations when establishing a chain of causation in acute exacerbation of asthma. First, the temporal sequence of TRAP, NOS and ARG methylation and FeNO is necessary when inferring causality. However, only five observational studies have examined the temporality [8-12]. Second, all but one of these studies relied on fixed-site measurements in assessing individual-level exposure, which may have biased associations between TRAP and respiratory outcomes compared to personal exposure measurements [12]. Third, none of the five studies focused on children with asthma, for whom respiratory inflammation plays a critical role in the exacerbation of this disease. One cohort study assessed the impacts of DNA methylation on FeNO in children [13]. They found that the strength of association between DNA methylation in ARG and FeNO was stronger in children with asthma compared to those without asthma.

We performed a longitudinal panel study, aimed to assess the effects of exposure to TRAP on FeNO and DNA methylation in promoter regions of NOS and ARG genes. We sampled buccal cells from children with asthma living in an urban, seaport-adjacent community in New Jersey. Using real-time measurement of personal exposure to black carbon as an indicator for TRAP exposure, we investigated the temporal patterns of DNA methylation and FeNO responses. We hypothesized that exposure to TRAP would be positively associated with the FeNO levels and methylation of $A R G$ genes, and negatively associated with methylation of NOS genes. We further hypothesized that the associations between TRAP and methylation would occur within a shorter lag period than the associations between TRAP and FeNO.

\section{Methods \\ Study population}

This study was nested in a panel study with repeated measurements on TRAP and FeNO. From 2011 to 2016, we repeatedly sampled 36 children from non-smoking households living in Newark or Elizabeth NJ with mild intermittent to moderate asthma by The National Heart, Lung, and Blood Institute (NHLBI) criteria [14]. All of the participants were taking an inhaled bronchodilator and/or inhaled corticosteroid, which was uninterrupted during the study. Each subject was followed for up to 30 days. Power calculations to examine the within-subject association between either exposure and methylation, or methylation and FeNO, were conducted via simulation. Simulations assumed 18 subjects with an average of 5 repeated measures per subject, using a sum across subjects of the fisher-transformed correlations within subject, which follows a normal distribution. Assuming we conducted a two-sided hypothesis test that the correlation was equal to zero, we would have $75.9 \%$ power to detect a correlation of 0.35 . For within-subject correlations of 0.40 and 0.45 , we would have powers of 85.7 and $92.1 \%$, respectively. Therefore, a subset of 18 children ( 5 buccal samples per child) was randomly selected for the DNA methylation study. The inclusion criteria are: subjects with at least five buccal cell samples; with FeNO measurements, and with less than $20 \%$ missing of 24-h BC data. The Institutional Review Board of Rutgers University approved the epigenetic study protocol. Parents or 
legal guardians provided informed consent for all subjects.

\section{FeNO measurements}

FeNO was measured using the NIOX MINO (Aerocrine, New Providence, NJ) following the manufacturer's instructions and the standards of the American Thoracic Society and the European Respiratory Society. Concentrations of NO were measured during 10-s exhalations of breath at an exhalation pressure of $10-20 \mathrm{cmH}_{2} \mathrm{O}$ to maintain a flow rate of $50 \pm 5 \mathrm{ml} / \mathrm{second}$. To control for the possible circadian effects, FeNO measurements were conducted at the same time (around 4:00 p.m.) for all subjects on the same day when collecting buccal cell samples.

\section{Buccal cell samples}

Buccal cell samples were collected at the community field site on various weekdays to better capture the variation in DNA methylation on different day-of-week. Each child was provided with two toothbrushes. They were instructed to remove all food from their mouths and used the first toothbrush to brush their teeth before buccal cell collection. After that, children were instructed to gently brushed buccal mucosa 10 strokes with the second toothbrush and then to rinse the mouth with water for $30 \mathrm{~s}$. Then the subjects were told to spit the content in a tube and put the second brush in the expelled water. Isopropyl alcohol $(70 \%)$ was added to the tube after sampling. In the lab, buccal cell suspensions were centrifuged at $2500 \mathrm{rpm}(1000 \mathrm{~g})$ for $15 \mathrm{~min}$. The pellets were stored frozen at $-80^{\circ} \mathrm{C}$ until used for DNA extraction.

\section{DNA methylation}

We studied CpG loci located in promoter regions of NOS1 (6 CpG sites), NOS2A (16 CpG sites), NOS3 (3 CpG sites), ARG1 (8 CpG sites) and ARG2 (13 CpG sites) genes. The rationale of selecting the location of the gene promoter, amplified regions, and $\mathrm{CpG}$ sites were supported by another study by Breton et al. [13]. Lab technicians who performed DNA methylation analysis were blinded to subject information. Genomic DNA was extracted from the cell pellets with QuickDNA 96 Kit (Zymo Res.) and $1 \mu \mathrm{g}$ DNA subjected to bisulfite conversion with EZ-96 DNA Methylation Kit (Deep-Well) (Zymo Res.) for downstream analyses, including polymerase chain reaction (PCR) and Pyrosequencing. Samples were then amplified by PCR and analyzed using a PSQHS96 Pyrosequencing System (EpigenDx, Hopkinton, MA). Methylation status at each CpG site was measured by calculating the ratio of $\mathrm{C}$ (methylated cytosine) relative to $\mathrm{T}$ (unmethylated cytosine) [15]. For each CpG site tested, the percentage of 5- methylcytosine $(\% 5 \mathrm{mC})$ was calculated and presented as the degree of methylation. For all assays, methylated and unmethylated DNA standards were used as positive and negative control, respectively to validate the method of bisulfite conversion and PCR amplification.

\section{Air pollutants}

Personal real-time $\mathrm{BC}$ data was recorded by microaethalometer (AE51, Aethlabs, Oakland, CA) for up to 30 consecutive days. Subjects carried the monitor on a belt during waking hours, and recharged the monitor at bedside while asleep. $\mathrm{NO}_{2}$ were sampled by passive personal sampler (Ogawa \& Co., Pompano Beach, FL) and analyzed by electron absorption spectroscopy. Then the integrated 24-h $\mathrm{NO}_{2}$ data were obtained for up to 30 consecutive days. Data cleaning algorithms were applied to address artifactual high and low $\mathrm{BC}$ readings from the aethalometer [16, 17].

\section{Lag periods}

FeNO data and buccal cell samples were collected around $4 \mathrm{p} . \mathrm{m} . \mathrm{BC}$ at lag $0-6 \mathrm{~h}$ and lag $7-12 \mathrm{~h}$ indicated the average $\mathrm{BC}$ from $10 \mathrm{a} . \mathrm{m}$. to $4 \mathrm{p} . \mathrm{m}$. and $4 \mathrm{a} . \mathrm{m}$. to 10 a.m. on the same day when collecting FeNO. BC at lag 13-24 $\mathrm{h}$ and lag $0-24 \mathrm{~h}$ indicated the average $\mathrm{BC}$ from 4 p.m. 1 day prior to $\mathrm{FeNO}$ measurement to 4 a.m. and to 4 p.m. on the same day when collecting FeNO. BC at lag $25-48 \mathrm{~h}$ indicated the average $\mathrm{BC}$ from $4 \mathrm{p} . \mathrm{m}$. 2 days to 4 p.m. 1 day prior to FeNO measurement. BC at lag 49 $72 \mathrm{~h}$ indicated the average $\mathrm{BC}$ from 4 p.m. 3 days to 4 p.m. 2 day prior to FeNO measurement. BC at lag $72-$ $96 \mathrm{~h}$ indicated the average $\mathrm{BC}$ from 4 p.m. 4 days to 4 p.m. 3 day prior to FeNO measurement.

\section{Covariates}

Demographic information, including age, gender, and race/ethnicity, were obtained through questionnaires completed by parent or legal guardiansat the beginning of the study.

\section{Statistical analysis}

We used SAS software version 9.4 for all analyses. Descriptive analyses were conducted to understand the distributions of air pollution, DNA methylation at each locus and FeNO measurements in general and by subject characteristics. Outcome and exposure were treated as continuous variables in all models. Spearman correlation assessed the associations of percent methylation between loci in the same gene. Since a significantly high correlation of DNA methylations between loci was observed, we applied multivariate analysis of variance (MANOVA) in generalized linear models to study the association between percent methylation and $\mathrm{BC}$ exposure while 
controlling for the correlation of $\% 5 \mathrm{mC}$ among loci in the same gene (Supplement Table 1-5).

For genes with statistically significant results in MANOVA tests, we fitted four linear mixed effect models to assess the effects of $\mathrm{BC}$ on FeNO and percent DNA methylation at multiple periods prior to the buccal sample collection (Fig. 1): 0-6h, 7-12 h, 13-24 h, 0-24h (lag 0 day), 25-48 h (lag 1 day) 49$72 \mathrm{~h}$ (lag 2 days) 73-96h (lag 3 days). The four models include: unadjusted model (model 1); model adjusted for week number and day-of-week when collecting the outcomes (model 2); model further adjusted for age, gender and race/ethnicity (model 3 ) and model further adjusted for $\mathrm{NO}_{2}$ (model 4). $\mathrm{BC}$ and all covariates were incorporated as fixed-effect terms while a random-effect term for each subject was added to account for the correlations of repeated measurements collected from the same subject.

All tests were 2-sided at a 5\% significance level. The effect estimates of DNA methylation were presented as the change and its 95\% confidence interval (CIs) in $\% 5 \mathrm{mC}$ per log-transformed and lag-specific interquartile range (IQR) increase in $\mathrm{BC}$. The effect estimates of $\mathrm{FeNO}$ were presented as the relative change and its 95\% CIs per log-transformed and lagspecific IQR increase in $\mathrm{BC}$.

Missing data problems are usually addressed by including only subjects without missing data in any variables required for an analysis. Such method is subject to bias and loss of information [18]. We conducted a sensitivity analysis by using multiple imputation for missing $\mathrm{BC}$ and $\mathrm{NO}_{2}$ data and fitted the same models to examine the lag patterns of imputed $\mathrm{BC}$, DNA methylation and FeNO levels (Supplement Table 7-8).

\section{Results}

Table 1 summarizes the basic personal characteristics of the participating subjects. On average, children were 10 years old, and $72 \%(n=13)$ were boys and $55 \%(n=10)$ were Hispanic. Distribution of percent methylation of CpG loci in NOS and ARG genes is shown in Supplement Table 1. The CpG loci located in intron 1 in NOS3 (position 1-3), 5-upstream in NOS2A (position 12, 13) and 5-untranslated region (5-UTR) in NOS1 (position 1-6) and NOS2A (position 14, 15) were methylated > $65 \%$ while the loci located in intron 2 in NOS2A (position 3-11) and 5-UTR in ARG2 (position 1-13) were nearly unmethylated (mean $\% 5 \mathrm{mC}<3 \%$ ). The average percent methylation of $\mathrm{CpG}$ sites in 5-upstream in ARG1 ranged from 5 to $91 \%$. The between-subject correlations of methylation at each locus varied by genes. Pearson correlations ranged from -0.08 to $0.79,-0.59$ to $0.91,0.40$ to 0.76 and -0.75 to 0.91 of the 6 sites in NOS1, the 16 sites in NOS2A, the 3 sites in NOS 3 and 8 sites in ARG1, respectively (Supplement Table 2-5).

The 24-h average $\mathrm{BC}$ prior to buccal sample collections ranged from $0.17 \mu \mathrm{g} / \mathrm{m}^{3}$ to $6.99 \mu \mathrm{g} / \mathrm{m}^{3}$, with an

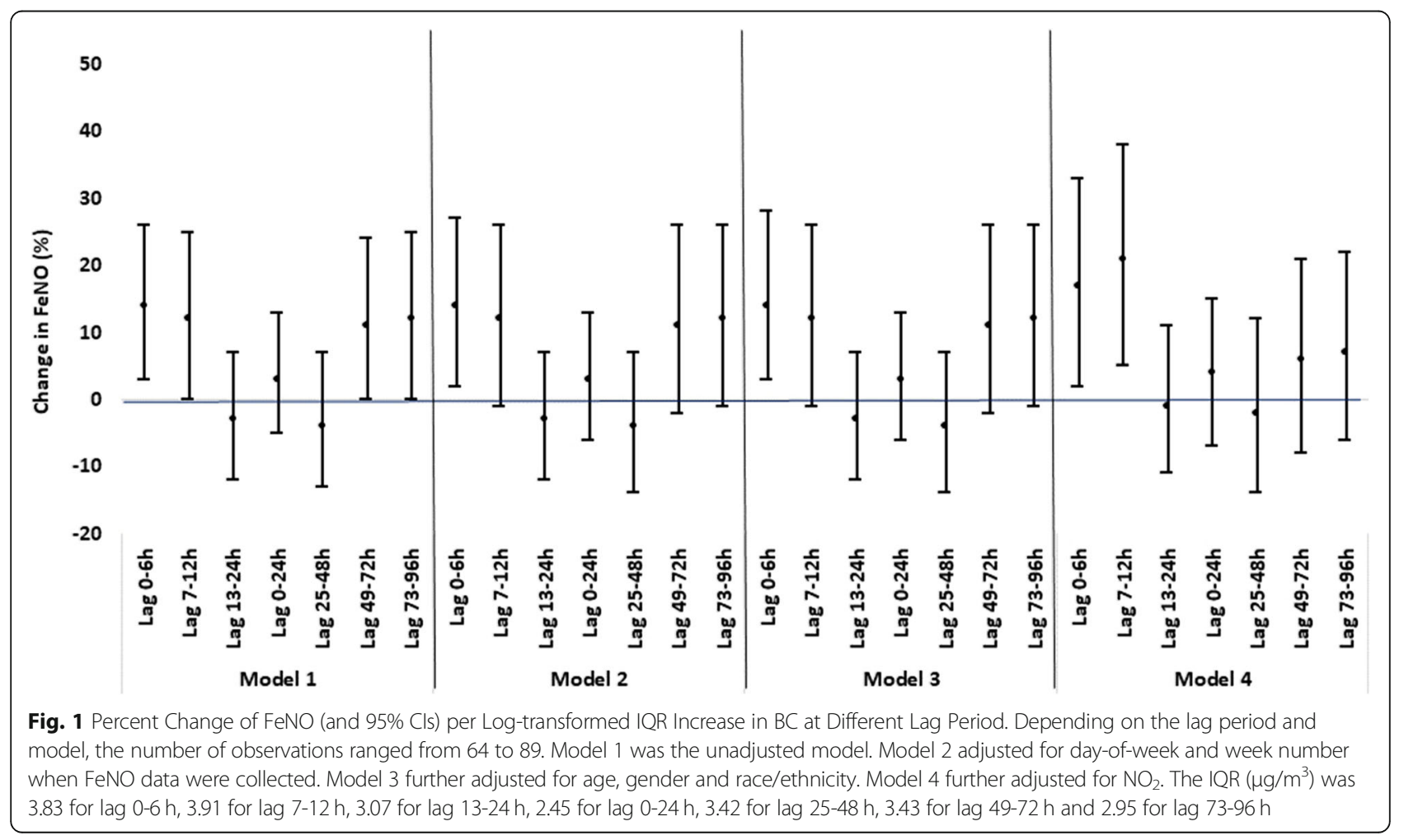


Table 1 Descriptive statistics of the study population $(n=18)$

\begin{tabular}{ll}
\hline Characteristic & Measure \\
\hline Age (years, mean \pm SD) & $10.6 \pm 1.7$ \\
Male n(\%) & $13(72.2)$ \\
Race/ethnicity n(\%) & \\
$\quad$ African American & $5(27.8)$ \\
Hispanic & $10(55.6)$ \\
White & $3(16.6)$ \\
Maternal education n(\%) & \\
$\quad<$ High school & $2(12.5)$ \\
High school graduate & $9(56.3)$ \\
Some college & $5(31.2)$ \\
\hline
\end{tabular}

average of $1.63 \mu \mathrm{g} / \mathrm{m}^{3}$ (Table 2). The level of FeNO varied substantially from $2.5 \mathrm{ppb}$ to $106 \mathrm{ppb}$ with a mean of $30.6 \mathrm{ppb}$ and a median of $17 \mathrm{ppb}$.

Table 3 and Fig. 1 summarize the effects of exposure to $\mathrm{BC}$ at various lag periods on $\mathrm{FeNO}$ using linear mixed-effect models. In the single-pollutant model, we found a $14 \%$ increase (95\%CI: 3-26\%) in FeNO per logtransformed IQR increase in $\mathrm{BC}$ at lag $0-6 \mathrm{~h}(p=0.01)$. The strength of associations decreased and became insignificant at longer lag periods. This trend remains after adjusting for age, gender, race/ethnicity, week number and day-of-week for FeNO data collection. In model 4, where we further adjusted for daily $\mathrm{NO}_{2}$ level, we observed a $17 \%$ increase (95\%CI: $3-28 \%)$ in FeNO at lag $0-6 \mathrm{~h}(p=0.02)$ and $21 \%$ increase $(95 \% \mathrm{CI}: 5-38 \%)$ in FeNO at lag $7-12 \mathrm{~h}(\mathrm{p}=0.01)$, both of which are stronger compared to the strength of association from singlepollutant models. The strength decreased and became insignificant at longer lag periods.

We applied the MANOVA test and found significant associations between percent methylation in the NOS3 gene and exposure to $\mathrm{BC}$ at two lag periods: $13-24 \mathrm{~h}$ (Wilks' Lambda $p=0.04$ ) and 0-24h (Wilks' Lambda $\mathrm{p}=0.04$ ) before buccal cell sample collection (Supplement Table 6). Thus, only NOS3 gene methylation data were used in the following analysis.

$\mathrm{BC}$ concentrations, in lag 7-12 $\mathrm{h}$, lag $13-24 \mathrm{~h}$ and 0 $24 \mathrm{~h}$, were negatively associated with the percent methylation in Position 1 in all mixed effect models (Table 4). At lag $7-12 \mathrm{~h}$, there was a $4.81 \%(95 \% \mathrm{CI}$ : $7.64,-1.99 \%)$ to $7.13 \%(95 \% \mathrm{CI}:-11.76,-2.50 \%)$ decreased methylation in Position 1 per log-transformed IQR increase in BC in model 1-4. At lag 13-24 h, a logtransformed IQR increase in BC in model 1-4 was associated with a $4.99 \%(95 \% \mathrm{CI}:-7.80-2.17 \%)$ to $8.12 \%$ (95\%CI: - $11.68-4.56 \%$ ) decreased methylation in Position 1. At lag 0 day, there was a $5.44 \%$ (95\% CI: -8.07 , $2.82 \%)$ to $6.79 \%$ (95\%CI: $-10.27,-3.31 \%$ ) decreased methylation in Position 1 per log-transformed IQR increase in $\mathrm{BC}$ in all regression models. In the singlepollutant model, a log-transformed IQR increase in BC at lag $13-24 \mathrm{~h}$ and lag 0 day was associated with $4.47 \%$ (95\%CI: $-7.51-1.43 \%$ ) and 3.13\% (95\%CI: $-5.73-0.53 \%)$ decreased methylation in Position 2. The strength of association became weaker and insignificant in model 4 . No significant associations were found in Position 3. BC concentrations at other lag periods were also tested to reveal the lag structure of changes in NOS3 methylation by $\mathrm{BC}$ (Fig. 2). We observed a decrease in methylation level in Position 1 immediately after exposure to $\mathrm{BC}(0-$ $6 \mathrm{~h}$ ) in the unadjusted model 1 . The methylation level became even lower at lag 7-12 h and lag 13-24 h, and then attenuated at longer lag periods. This trend remains for the adjusted models. Similar lag structures were observed for Position 2 and 3. In model 4, we found significant decrease in methylation level in Position 1 in response to $\mathrm{BC}$ exposure within the first $48 \mathrm{~h}$ after $\mathrm{BC}$ exposure. The associations became insignificant at longer lag periods.

There was a small fraction (7-9\%) of missing data for $\mathrm{BC}$ during the selected lag periods and $17 \%$ missing data for daily $\mathrm{NO}_{2}$. We used multiple imputation to fill in the missing $\mathrm{BC}$ and $\mathrm{NO}_{2}$ data. The mean (SD) of 24-h average $\mathrm{BC}$ and $\mathrm{NO}_{2}$ with vs. without imputation were $1.63 \mu \mathrm{g} / \mathrm{m}^{3}$ (1.36) vs. $1.43 \mu \mathrm{g} / \mathrm{m}^{3}$ (1.22) and $40.63 \mathrm{ppb}$ (25.07) vs. $41.67 \mathrm{ppb}$ (23.17), respectively (Table 2). From MANOVA test results, the same gene and lag $\mathrm{BC}$ periods were identified using the imputed BC (Supplement Table 6). We found similar associations between $\mathrm{FeNO}$ and $\mathrm{BC}$ with or without imputation (Supplement Table 7). Compared with the non-imputed $\mathrm{BC}$, the imputed $\mathrm{BC}$ had slightly

Table 2 Distribution of $\mathrm{BC}$, daily average $\mathrm{NO}_{2}$, and FeNO

\begin{tabular}{|c|c|c|c|c|c|c|c|c|c|c|}
\hline & & $N$ & Mean & SD & IQR & 25th & Median & 75th & Min & Max \\
\hline \multirow[t]{2}{*}{$\mathrm{BC}\left(\mu \mathrm{g} / \mathrm{m}^{3}\right)$} & without Ml & 90 & 1.6 & 1.4 & 1.1 & 0.8 & 1.1 & 1.9 & 0.2 & 7.0 \\
\hline & with Ml & 90 & 1.4 & 1.2 & 1.0 & 0.7 & 1.0 & 1.6 & 0.2 & 6.2 \\
\hline \multirow[t]{2}{*}{$\mathrm{NO}_{2}(\mathrm{ppb})$} & without Ml & 74 & 40.6 & 25.1 & 27.9 & 23.3 & 36.7 & 51.2 & 3.4 & 138.3 \\
\hline & with Ml & 90 & 41.7 & 23.2 & 26.2 & 25.3 & 39.3 & 51.5 & 3.4 & 138.3 \\
\hline FeNO (ppb) & & 89 & 30.6 & 28.3 & 42.0 & 9.0 & 17.0 & 51.0 & 2.5 & 106.0 \\
\hline
\end{tabular}

$\mathrm{BC}$ data were measured 24-h before buccal sample collection

Abbreviations: $B C$ black carbon, NO2 nitrogen dioxide, FeNO fractional exhaled nitric oxide, MI multiple imputation, IQR interquartile range 
Table 3 Relative changes in FeNO per log-transformed IQR increase in BC at different lag periods

\begin{tabular}{|c|c|c|c|c|c|c|c|c|c|c|c|c|}
\hline \multirow[t]{2}{*}{ Lag } & \multicolumn{2}{|r|}{ Model 1} & \multirow[t]{2}{*}{ p } & \multicolumn{2}{|r|}{ Model 2} & \multirow[t]{2}{*}{$p$} & \multicolumn{2}{|r|}{ Model 3} & \multirow[t]{2}{*}{$p$} & \multicolumn{2}{|r|}{ Model 4} & \multirow[t]{2}{*}{$p$} \\
\hline & $\bar{n}$ & $\begin{array}{c}\text { Relative change in } \\
\text { FeNO }(95 \% \mathrm{Cl})\end{array}$ & & $\bar{n}$ & $\begin{array}{l}\text { Relative change in } \\
\text { FeNO }(95 \% \mathrm{Cl})\end{array}$ & & $\bar{n}$ & $\begin{array}{c}\text { Relative change in } \\
\text { FeNO }(95 \% \mathrm{Cl})\end{array}$ & & $\bar{n}$ & $\begin{array}{l}\text { Relative change in } \\
\text { FeNO }(95 \% \mathrm{Cl})\end{array}$ & \\
\hline ag $0-6 h$ & 89 & $1.14(1.03,1.26)$ & 0.01 & 89 & $1.14(1.02,1.27)$ & 0.02 & 89 & $1.14(1.03,1.28)$ & 0.02 & 73 & $1.17(1.02,1.33)$ & 0.0 \\
\hline Lag 7-12 h & 89 & $1.12(1.00,1.25)$ & 0.06 & 89 & $1.12(0.99,1.26)$ & 0.07 & 89 & $1.12(0.99,1.26)$ & 0.07 & 73 & $1.21(1.05,1.38)$ & $0 .($ \\
\hline g $13-24 h$ & 89 & $0.97(0.88,1.07)$ & 0.55 & 89 & $0.97(0.88,1.07)$ & 0.55 & 89 & $0.97(0.88,1.07)$ & 0.54 & 73 & $0.99(0.8$ & 0. \\
\hline Lag 0-24 h & 89 & $1.03(0.95,1.13)$ & 0.45 & 89 & $1.03(0.94,1.13)$ & 0.52 & 89 & $1.03(0.94,1.13)$ & 0.53 & 73 & $1.04(0.93,1.15)$ & 0.49 \\
\hline ag $25-48 \mathrm{~h}$ & 86 & $0.96(0.87,1.07)$ & 0.47 & 86 & $0.96(0.86,1.07)$ & 0.49 & 86 & $0.96(0.86,1.07)$ & 0.47 & 70 & $0.98(0.86,1.12)$ & 0. \\
\hline Lag 49-72 h & 83 & $1.11(1.00,1.24)$ & 0.06 & 83 & $1.11(0.98,1.26)$ & 0.09 & 83 & $1.11(0.98,1.26)$ & 0.09 & 67 & $1.06(0.92,1.21)$ & 0.44 \\
\hline Lag 73-96 h & 80 & $1.12(1.00,1.25)$ & 0.06 & 80 & $1.12(0.99,1.26)$ & 0.07 & 80 & $1.12(0.99,1.26)$ & 0.07 & 64 & $1.07(0.94,1.22)$ & 0.32 \\
\hline
\end{tabular}

Note: All estimates are from linear mixed effect model to reflect percent changes in FeNO per IQR increase in log-transformed BC. The IQR ( $\mu \mathrm{g} / \mathrm{m}^{3}$ ) was 1.8 for lag 0-6 h, 1.8 for lag 7-12 h, 1.2 for lag 13-24 h, 1.1 for lag 0-24 h, 1.5 for lag 25-48 h, 1.6 for lag 49-72 h and 1.3 for lag 73-96 h

Model 1 was the unadjusted model

Model 2 adjusted for day-of-week and week number when FeNO data were collected

Model 3 further adjusted for age, gender and race/ethnicity

Model 4 further adjusted for $\mathrm{NO}_{2}$

stronger negative associations with the methylation in NOS3 in all models (Supplement Table 8).

We also tested the associations between percent methylation in NOS and ARG1 genes and FeNO at lag 1 day. In the unadjusted model, we observed a 3\% (95\%CI: 0-6\%) increase in FeNO per percent increase in methylation in ARG1 Position 2. We did not find statistically significant associations with methylation at other positions in NOS and ARG genes.

\section{Discussion}

We found that personal exposure to $\mathrm{BC}$, as a marker for TRAP, was positively associated with $\mathrm{FeNO}$ at lag periods of less than $12 \mathrm{~h}$ in children with asthma. To better understand the mode of action by which exposure to TRAP may increase FeNO, we examined associations between exposure to $\mathrm{BC}$ and DNA methylation levels in promoter regions of $N O S$ and $A R G$ genes. We found that exposure to $\mathrm{BC}$ was negatively associated only with methylation of the NOS3 gene, suggesting that modulation of this "constitutive" isoform of NOS may be involved in short-term changes in FeNO associated with exposure to TRAP.

Consistent with previous studies, we observed a significant increase in $\mathrm{FeNO}$ in response to $\mathrm{BC}$ exposure in children with asthma. As a non-invasive biomarker of inflammation, FeNO has been reported to be positively associated with TRAP in epidemiological studies, especially in patients with preexisting asthma and COPD $[3,8]$. Nitric oxide normally functions as a key physiological mediator in human immune responses and smooth muscle relaxation. However, overproduction of $\mathrm{NO}$ may mediate cellular toxicity and cause inflammation $[19,20]$. Airway inflammation is a key mechanism in the pathogenesis of asthma exacerbation [21]. However, the biological mechanisms linking the TRAP exposure to airway inflammation and increased FeNO remain unclear.

Results from prior human studies have been inconsistent, but most studies revealed that exposure to particulate air pollutants decreased NOS $2 A$ promoter methylation and increased $A R G$ methylation. In a cohort of 163 urban children, Jung et al. found that higher level of 24-h BC measured by personal monitors were associated with reduced methylation of NOS2A 5 days later [22]. The magnitude of association was stronger among the seroatopic and cockroach-sensitized children compared to nonsensitized children. In the Southern California Children's Health Study cohort, Salam et al. reported that elevated 7-day average exposure to $\mathrm{PM}_{2.5}$ was associated with a statistically significant decrease in NOS $2 \mathrm{~A}$ methylation in 940 children [9]. Using the same cohort, Breton et al. found significantly lower NOS $2 \mathrm{~A}$ methylation and higher NOS3 methylation in response to acute and chronic exposure to particulate matter [10]. Similar results were observed in panel studies of exposure to PM in China among 43 healthy adults and 30 adults with chronic obstructive pulmonary disease $[8,11]$. However, one panel study revealed that occupational exposure to fine PM was positively associated with increased NOS $2 A$ methylation in 38 male boilermaker welders [23].

Based on these previous studies, we hypothesized, that exposure to TRAP would be negatively associated with DNA methylation in NOS genes, especially NOS $2 A$, and positively associated with methylation in $A R G$ genes in children with asthma exposed to BC. We found statistically significant negative associations between exposure to $\mathrm{BC}$ and NOS3 promoter methylation only. In contrast, in Breton et al., $\mathrm{PM}_{2.5}$ was associated with increased methylation levels in the NOS3 gene among children. 


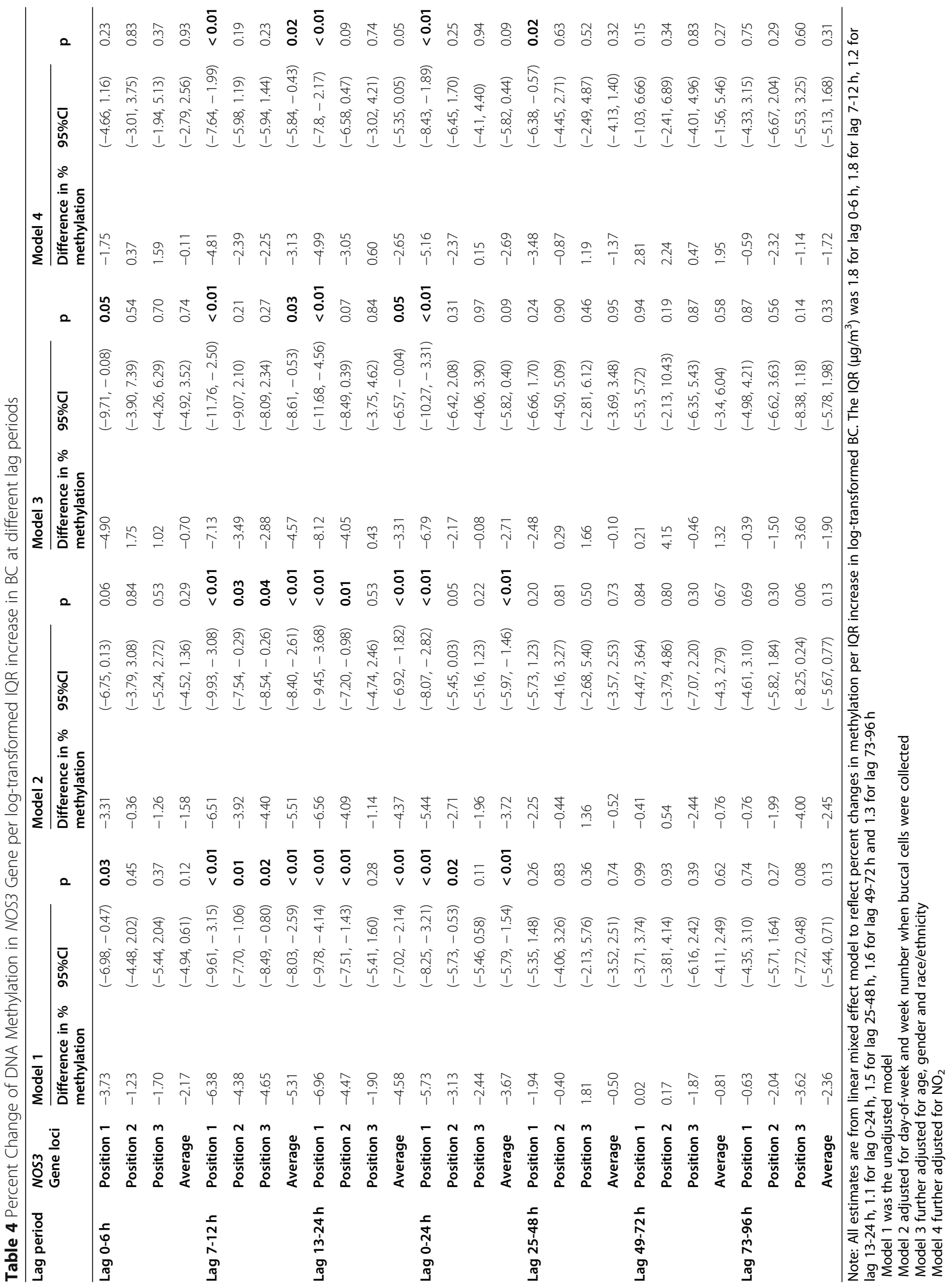




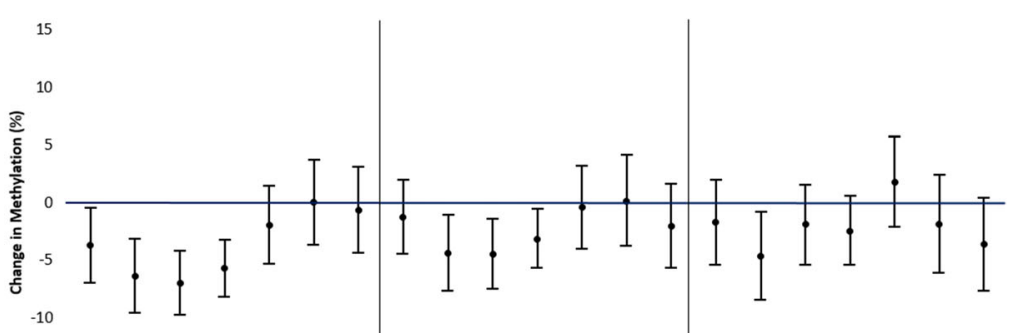

$-15$

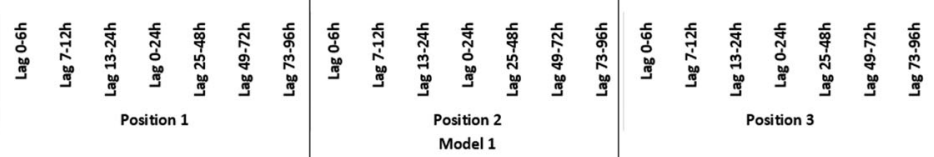

15

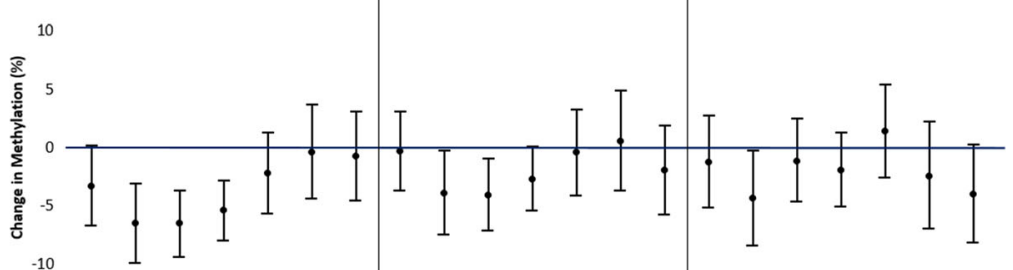

$-15$
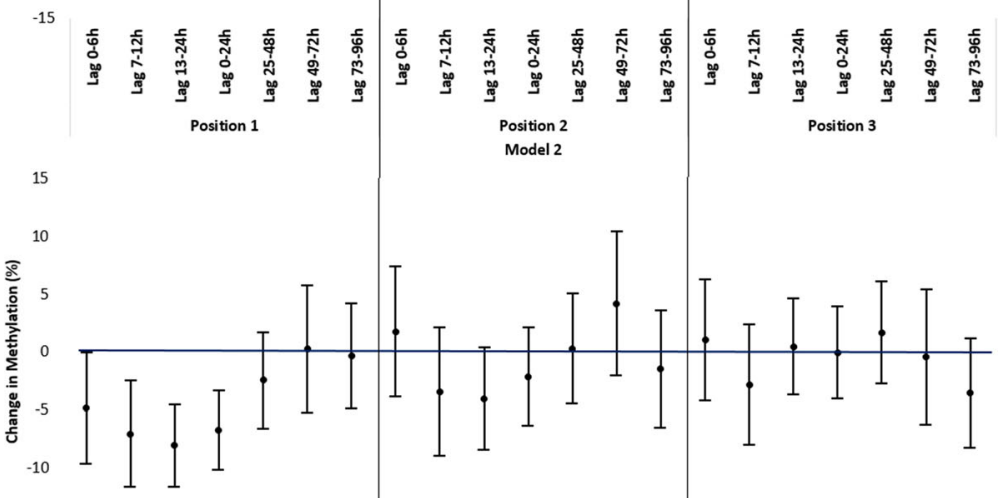

$-15$
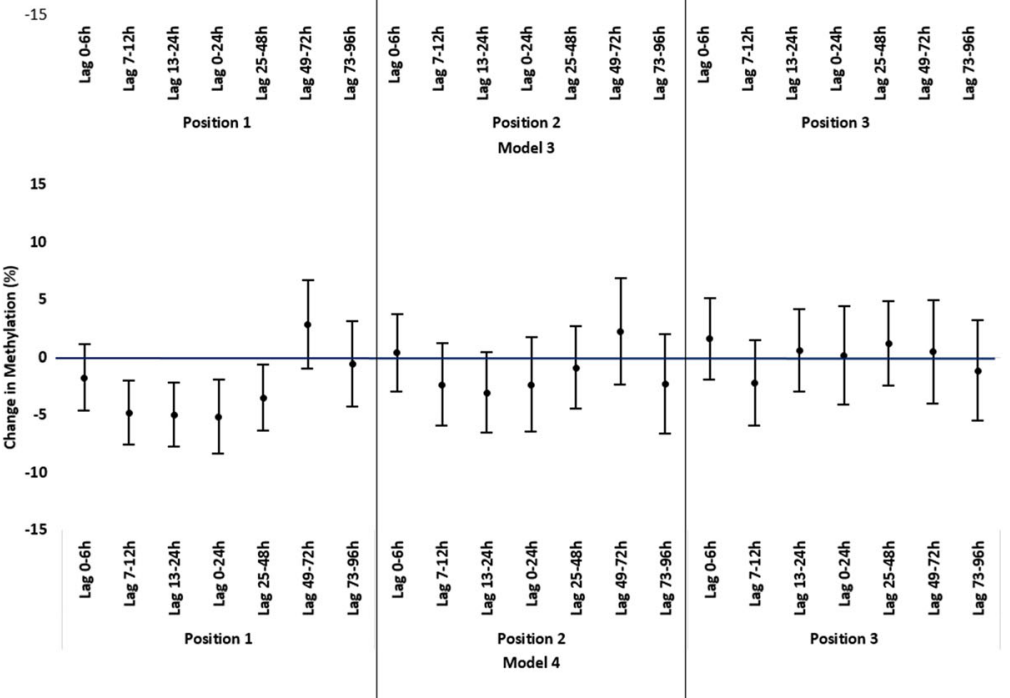

Fig. 2 (See legend on next page.) 
(See figure on previous page.)

Fig. 2 Change of Methylation in NOS3 Gene per Log-transformed IQR Increase in BC at Different Lag Period in Model 1-4. Depending on the lag period, position of the loci and the model, the number of observations ranged from 62 to 86 . Model 1 was the unadjusted model. Model 2 adjusted for day-of-week and week number when FeNO data were collected. Model 3 further adjusted for day-of-week, week number when FeNO data were collected, age, gender and race/ethnicity. Model 4 further adjusted for $\mathrm{NO}_{2}$

Unlike previous studies, we did not find significant changes in the methylation level in other NOS and ARG isoforms in response to TRAP [10]. These inconsistent results could be due to several differences between our study and the previous studies, including differences in the study populations (children vs. adults, and asthma vs. other health conditions), exposure assessment approaches (personal vs. fixed-site monitoring) and the selection of CpG sites tested [8, 10, 11, 22, 23].

To further explore the role of DNA methylation in the associations of TRAP and FeNO in children with asthma, we examined the changes of NOS methylation and FeNO levels in response to TRAP at different timelag periods. We found that the negative effect of $\mathrm{BC}$ on NOS3 methylation at position 1 was stronger in the first $24 \mathrm{~h}$. The largest effect of $\mathrm{BC}$ on FeNO was found within $12 \mathrm{~h}$, and then both strengths of association decreased and became statistically insignificant. Unlike NOS $2 A$, which is inducible, NOS3 is expressed constitutively. In our previous controlled experimental studies, we found an immediate but transient increase in nitrite, a stable metabolite of $\mathrm{NO}$, in the exhaled breath condensate (EBC) of healthy young adults after exposure to TRAP particles and adults with asthma after exposure to diesel engine exhaust $[24,25]$. Such transient increases in EBC nitrite could be explained by rapid increases in either $\mathrm{NO}$ production or oxidation of NO to nitrite. However, in the current study, we did not find the expected association between methylation at the NOS3 position 1 locus and FeNO at lag day 1.

Our study has several strengths. We followed our subjects for up to 30 consecutive days. This study design addresses the temporality between exposure and outcomes, and the repeated sampling of the same subject increased the study power. Furthermore, personal real-time BC measurement likely reduced exposure measurement error compared with data from fixed-site monitors that were used in most of the previous studies. The nondifferential exposure measurement error could severely attenuate exposure-disease associations in epidemiological studies. For example, Niu et al. compared the associations of DNA methylation in NOS2A and ARG2 with personal and central-site monitored ozone exposure and found much stronger associations of ozone using personal measurements [12]. To avoid multiple pairwise comparisons, we applied the MANOVA test at multiple CpG loci in NOS and ARG genes. To reduce the unknown impacts of time-varying patterns, we collected buccal cells and FeNO on various day-of-week. Unlike most studies that only focused on CpG sites in $N O S 2 A$, our study tested multiple CpG loci at all isoforms of NOS and $A R G$, both of which are involved in the regulation of NO production. Finally, we focused on children with asthma living in environmental justice communities. This specific subpopulation may be more sensitive to short-term changes in exposure to TRAP.

Nonetheless, this study has certain limitations. Our study had very limited sample size, which was justified using power calculation that assumed one outcome and exposure at one lag period. In the analysis, we controlled for multiple testing across responses by using a Multivariate Analysis of Variance, such that the overall test of all responses for an exposure was conducted at the 0.05 level before looking at individual responses. Therefore, our study may have been underpowered for looking at the responses relative to an exposure. Because the $\mathrm{BC}$ collected at each lag period were highly correlated we could not include multiple lags in the regression models at once and we were not able to conclusively say that one lag was more influential than another. Due to the limited sample size, we were unable to check if the time lag pattern between exposure to TRAP and DNA methylation level varies by the degree of asthma.

Besides DNA methylation, there are several types of epigenetic modifications, including histone modification and miRNA expression, which could be impacted by air pollution exposures and could affect the development and exacerbation of asthma [26-28]. However, this is beyond the scope of this paper and future studies should be done in assessing the impacts of personal TRAP exposure on histone mondification and miRNA levels in children with asthma. We used buccal cells as surrogates for cells from bronchial tissue due to the feasibility of collection in a community based study of children with asthma. Studies have found similar gene expression, as well as methylation level in buccal cells and cells from the respiratory tract in response to tobacco, supporting the potential of the oral epithelium as a surrogate tissue for respiratory epithelium $[29,30]$. Other studies, noted above, have found associations between exposure to air pollution and changes in methylation in NOS genes from buccal cells [9-12, 22].

\section{Conclusions}

In this study, we found that exposure to TRAP was associated with higher levels of FeNO and lower levels of 
DNA methylation in the promoter regions of the NOS3 gene at various lag periods in children with asthma living in a seaport-adjacent community with high density of diesel truck traffic. Although these findings may not be generalizable to other populations, our results expand the understanding that DNA methylation of NOS genes could be an important biological mechanism in physiological responses to TRAP in children with asthma. To better understand the biological mechanism, future studies are needed to assess the interaction between the TRAP, epigenetic and genetic variation, airway production of NO and inflammation, and clinical outcomes.

\section{Supplementary Information}

The online version contains supplementary material available at https://doi. org/10.1186/s12940-020-00678-8.

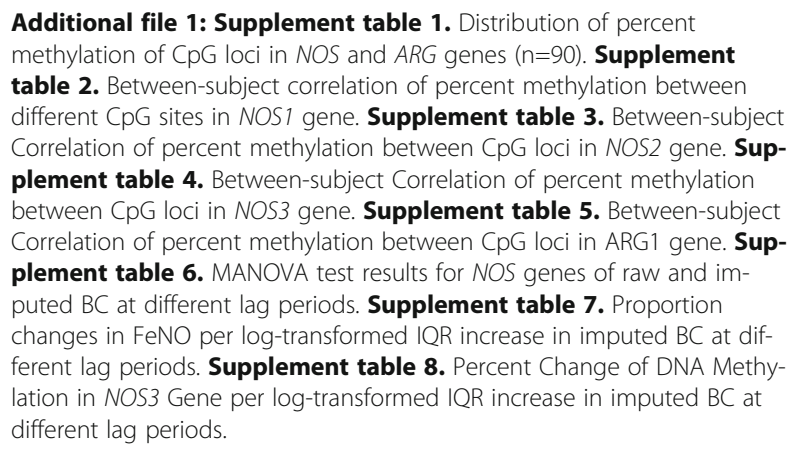

\section{Abbreviations}

ARG: Arginase; BC: Black carbon; CO: Carbon monoxide; EBC: Exhaled breath condensate; FeNO: Fractional exhaled nitric oxide; HEl: Health Effect Institute; IQR: Interquartile range; MANOVA: Multivariate analysis of variance; NHLBI: The National Heart, Lung, and Blood Institute; NO: Nitric oxide; NOS: NO synthase; NOS1: Neuronal NOS; NOS2A: Inducible NOS; NOS3: Endothelial NOS; NOx: Oxides of nitrogen; PM: Particulate matter; PCR: Polymerase chain reaction; TRAP: Traffic-related air pollution; VOCs: Volatile organic compounds; $\% 5 \mathrm{mC}$ : percentage of 5-methylcytosine; 5-UTR: 5-untranslated region; 95\% Cls: 95\% confidence interval

\section{Acknowledgements}

Not applicable.

\section{Authors' contributions}

All authors contributed to the conception and/or design of this study; data interpretation; writing, and critical revision of the manuscript; and approved the final version to be published. AB, CC, MG, ICM, NF and RJL contributed to the acquisition of the data. NJ, MF, POS, FH and RJL contributed to the analysis of the data.

\section{Funding}

This work was supported by grant USEPA RD-83457901 from the U.S. Environmental Protection Agency (USEPA). Additional support was provided by an award from National Institute of Environmental Health Science (NIEHS) P30ES005022.

\section{Availability of data and materials}

The datasets used and/or analysed during the current study are available from the corresponding author on reasonable request.

\section{Ethics approval and consent to participate}

The Institutional Review Board of Rutgers University approved the epigenetic study protocol. Parents or legal guardians provided informed consent for all subjects.

\section{Consent for publication}

Not applicable.

\section{Competing interests}

The authors declare that they have no competing interests.

\section{Author details}

${ }^{1}$ Rutgers, The State University of New Jersey, 170 Frelinghuysen Rd, Room 204, Piscataway, NJ 08854, USA. ${ }^{2}$ The New School, New York, NY, USA.

3 Ironbound Community Corporation, Newark, NJ, USA.

Received: 16 July 2020 Accepted: 13 November 2020

Published online: 11 February 2021

\section{References}

1. Health Effects Institute. HEl Panel on the Health Effects of Traffic-Related Air Pollution. Traffic-related air pollution: a critical review of the literature on emissions, exposure, and health effects. 2010.

2. Eckel SP, Zhang Z, Habre R, Rappaport EB, Linn WS, Berhane K, et al. Trafficrelated air pollution and alveolar nitric oxide in southern California children. Eur Respir J. 2016;47(5):1348-56.

3. Delfino RJ, Staimer N, Gillen D, Tjoa T, Sioutas C, Fung K, et al. Personal and ambient air pollution is associated with increased exhaled nitric oxide in children with asthma. Environ Health Perspect. 2006;114(11):1736-43.

4. Salam MT, Lin PC, Eckel SP, Gauderman WJ, Gilliland FD. Inducible nitric oxide synthase promoter haplotypes and residential traffic-related air pollution jointly influence exhaled nitric oxide level in children. PLoS One. 2015;10(12):e0145363.

5. Jones SL, Kittelson J, Cowan JO, Flannery EM, Hancox RJ, McLachlan CR, et al. The predictive value of exhaled nitric oxide measurements in assessing changes in asthma control. Am J Respir Crit Care Med. 2001; 164(5):738-43.

6. Forstermann $U$, Sessa WC. Nitric oxide synthases: regulation and function. Eur Heart J. 2012;33(7):829-37 37a-37d.

7. Bratt JM, Zeki AA, Last JA, Kenyon NJ. Competitive metabolism of L-arginine: arginase as a therapeutic target in asthma. J Biomed Res. 2011;25(5):299308.

8. Chen R, Qiao L, Li H, Zhao Y, Zhang Y, Xu W, et al. Fine particulate matter constituents, nitric oxide synthase DNA methylation and exhaled nitric oxide. Environ Sci Technol. 2015;49(19):11859-65.

9. Salam MT, Byun HM, Lurmann F, Breton CV, Wang X, Eckel SP, et al. Genetic and epigenetic variations in inducible nitric oxide synthase promoter, particulate pollution, and exhaled nitric oxide levels in children. J Allergy Clin Immunol. 2012;129(1):232-9 e1-7.

10. Breton CV, Salam MT, Wang X, Byun HM, Siegmund KD, Gilliland FD. Particulate matter, DNA methylation in nitric oxide synthase, and childhood respiratory disease. Environ Health Perspect. 2012;120(9):1320-6.

11. Zhang $Q$, Wang W, Niu Y, Xia Y, Lei $X$, Huo J, et al. The effects of fine particulate matter constituents on exhaled nitric oxide and DNA methylation in the arginase-nitric oxide synthase pathway. Environment International. 2019;131(March):105019-.

12. Niu Y, Chen R, Xia Y, Cai J, Lin Z, Liu C, et al. Personal ozone exposure and respiratory inflammatory response: the role of DNA methylation in the Arginase-nitric oxide synthase pathway. Environ Sci Technol. 2018;52(15): 8785-91.

13. Breton CV, Byun HM, Wang X, Salam MT, Siegmund K, Gilliland FD. DNA methylation in the arginase-nitric oxide synthase pathway is associated with exhaled nitric oxide in children with asthma. Am J Respir Crit Care Med. 2011;184(2):191-7.

14. National Asthma Education Prevention Program. Expert panel report 3 (EPR3): guidelines for the diagnosis and Management of Asthma-Summary Report 2007. J Allergy Clin Immunol. 2007;120(5 Suppl):S94-138.

15. Tost J, Gut IG. DNA methylation analysis by pyrosequencing. Nat Protoc. 2007;2(9):2265-75 
16. Kirchstetter TW, Novakov T. Controlled generation of black carbon particles from a diffusion flame and applications in evaluating black carbon measurement methods. Atmos Environ. 2007;41 (9):1874-88.

17. Cai J, Yan B, Kinney PL, Perzanowski MS, Jung KH, Li T, et al. Optimization approaches to ameliorate humidity and vibration related issues using the microAeth black carbon monitor for personal exposure measurement. Aerosol Sci Technol. 2013;47(11):1196-204.

18. Sterne JA, White IR, Carlin JB, Spratt M, Royston P, Kenward MG, et al. Multiple imputation for missing data in epidemiological and clinical research: potential and pitfalls. BMJ. 2009;338:b2393.

19. Guzik TJ, Korbut R, Adamek-Guzik T. Nitric oxide and superoxide in inflammation and immune regulation. J Physiol Pharmacol. 2003;54(4):46987.

20. Bredt DS. Endogenous nitric oxide synthesis: Biological functions and pathophysiology. 1999:31:577-96

21. Wark PA, Gibson PG. Asthma exacerbations. 3: Pathogenesis. Thorax. 2006; 61(10):909-15.

22. Jung KH, Lovinsky-Desir S, Yan BZ, Torrone D, Lawrence J, Jezioro JR, et al. Effect of personal exposure to black carbon on changes in allergic asthma gene methylation measured 5 days later in urban children: importance of allergic sensitization. Clin Epigenetics. 2017;9:61.

23. Kile ML, Fang S, Baccarelli AA, Tarantini L, Cavallari J, Christiani DC. A pane study of occupational exposure to fine particulate matter and changes in DNA methylation over a single workday and years worked in boilermaker welders. Environ Health. 2013;12(1):47.

24. Laumbach RJ, Kipen HM, Ko S, Kelly-McNeil K, Cepeda C, Pettit A, et al. A controlled trial of acute effects of human exposure to traffic particles on pulmonary oxidative stress and heart rate variability. Part Fibre Toxicol. 2014;11:45.

25. Hussain S, Laumbach R, Coleman J, Youssef H, Kelly-McNeil K, OhmanStrickland P, et al. Controlled exposure to diesel exhaust causes increased nitrite in exhaled breath condensate among subjects with asthma. J Occup Environ Med. 2012;54(10):1186-91.

26. Shukla A, Bunkar N, Kumar R, Bhargava A, Tiwari R, Chaudhury K, et al. Air pollution associated epigenetic modifications: Transgenerational inheritance and underlying molecular mechanisms. Sci Total Environ. 2019;656:760-77.

27. Zheng Y, Sanchez-Guerra M, Zhang Z, Joyce BT, Zhong J, Kresovich JK, et al. Traffic-derived particulate matter exposure and histone $\mathrm{H} 3$ modification: a repeated measures study. Environ Res. 2017;153:112-9.

28. Salam MT, Zhang Y, Begum K. Epigenetics and childhood asthma: current evidence and future research directions. Epigenomics. 2012;4(4):415-29.

29. Sridhar S, Schembri F, Zeskind J, Shah V, Gustafson AM, Steiling K, et al. Smoking-induced gene expression changes in the bronchial airway are reflected in nasal and buccal epithelium. BMC Genomics. 2008;9:259.

30. Bhutani M, Pathak AK, Fan YH, Liu DD, Lee JJ, Tang H, et al. Oral epithelium as a surrogate tissue for assessing smoking-induced molecular alterations in the lungs. Cancer Prev Res (Phila). 2008;1(1):39-44.

\section{Publisher's Note}

Springer Nature remains neutral with regard to jurisdictional claims in published maps and institutional affiliations.

\section{Ready to submit your research? Choose BMC and benefit from:}

- fast, convenient online submission

- thorough peer review by experienced researchers in your field

- rapid publication on acceptance

- support for research data, including large and complex data types

- gold Open Access which fosters wider collaboration and increased citations

- maximum visibility for your research: over $100 \mathrm{M}$ website views per year

At $\mathrm{BMC}$, research is always in progress.

Learn more biomedcentral.com/submissions 